\title{
PRESCRIPTION DRUG (RX) EVOLUTION IN ROMANIA BETWEEN 2010 AND 2020
}

\author{
PETRU CRĂCIUN ${ }^{1}$, MARIAN PANĂ $^{1 *}$, DUMITRU LUPULIASA ${ }^{1}$, MARIA-DORINA CRĂCIUN $^{2}$, \\ ADRIANA-ELENA TĂEREL ${ }^{3}$ \\ IPharmaceutical Technology and Biopharmacy Department, Faculty of Pharmacy, "Carol Davila” University of Medicine \\ and Pharmacy, Bucharest, Romania \\ ${ }^{2}$ Department of Epidemiology, Faculty of Medicine, "Carol Davila" University of Medicine and Pharmacy, Bucharest, \\ Romania \\ ${ }^{3}$ Department of Pharmaceutical Management and Marketing, Faculty of Pharmacy, "Carol Davila" University of Medicine \\ and Pharmacy, Bucharest, Romania
}

*corresponding author: marian.pana@ colegfarm.ro

Manuscript received: January 2021

\begin{abstract}
In Romania, there were implemented measures to reduce pharmaceutical expenditure, in line with other European countries.

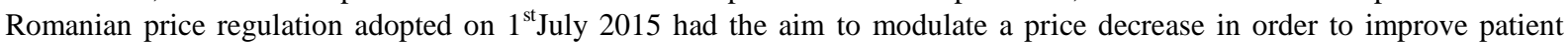
access to effective and affordable treatment, influencing the pharmaceutical market. As sufficient time has passed, we analysed the evolution of the prescription drug $(\mathrm{Rx})$ segment and proposed improvements of the regulation. The main finding is that the first 30 treatment groups, which account for two-thirds of drug volume and over $80 \%$ of total treatment days, benefit from less than $40 \%$ of value, which poses a diffuse but very serious risk for the availability of drugs frequently used and therapeutically important. The second finding is that the growth rate in the rest of the therapeutic groups is significant, which affects the sustainability of the system and its budgetary balance. An average price mechanism for Rx drugs from therapeutic groups whose average prices do not exceed 50 RON (equivalent of $10 €$ ) and a QALY (Quality-Adjusted Life Year) mechanism, plus other specific criteria, for groups that do not fall into the previous condition would be much more reasonable approaches for the Rx medicines prospects in Romania.
\end{abstract}

\section{Rezumat}

În România, au fost implementate măsuri de reducere a cheltuielilor farmaceutice, în conformitate cu alte țări europene. Reglementarea prețurilor din România adoptată pe 1 iulie 2015 a avut ca scop modularea unei scăderi a prețului pentru a îmbunătăți accesul pacienților la un tratament eficient și accesibil, influențând piața farmaceutică. Beneficiind de trecerea unui interval suficient de timp, am analizat evoluția segmentului medicamentelor eliberate pe o prescripție medicală $(\mathrm{Rx})$ și am propus îmbunătățiri în reglementarea acestuia. Principala constatare este că primele 30 de grupe terapeutice, care înseamnă două treimi din volumul medicamentelor și peste $80 \%$ din totalul zilelor de tratament, beneficiază de sub $40 \%$ din valoare, ceea ce prezintă un risc difuz, dar foarte serios, pentru disponibilitatea unor medicamente frecvent utilizate şi importante terapeutic. A doua constatare este că ritmul de creștere în restul grupelor terapeutice este semnificativ, ceea ce afectează sustenabilitatea sistemului și echilibrul bugetar al acestuia. Un mecanism de tip medie de preț pentru medicamentele Rx din grupele terapeutice al căror prețuri medii nu depășesc 50 lei (echivalentul a $10 €$ ) și un mecanism de tip QALY (QualityAdjusted Life Year), plus alte criterii specifice, pentru grupele care nu se încadrează în condiția precedentă ar fi abordări mult mai rezonabile pentru perspectiva tratamentului cu medicamente în România pentru viitor.

Keywords: Rx, ATC3, days of treatment, average price

\section{Introduction}

The landscape of the pharmaceutical market has been changing over the last years. The medicines use has led to high healthcare expenditures globally (around $1.3 \$$ trillion in 2020), being estimated an increase of $3-6 \%$ every year $[24,20]$. Countries around the world have tried to control pharmaceutical spending by introducing different price regulations [9]. The most encountered regulation measure was the external reference pricing (ERP), applied for all drugs or specific classes [7]. The calculation methods are different across European countries, being based on the average price (15 countries: Austria, Cyprus, Denmark, Belgium), the lowest price of reference countries (7 countries: Bulgaria, Romania, Hungary) or other calculation ways (7 countries) $[21,28]$. The main goal was to assure patient access to drugs, rising the adherence to treatment by providing affordable medicines [31]. In Romania, ERP regulation is the main method for price setting, applied to all medicines and being revised annually [7, 11]. Prescription drug evolution was seriously influenced by the price regulation adopted on $1^{\text {st }}$ July, 2015 ("the 
FARMACIA, 2021, Vol. 69, 5

smallest European price policy") [33]. A study evaluated the consequences of the policy over the Romanian prescription drug market during 2015 2019 [5]. It was found that cost-containment was accompanied by withdrawal or shortages of many medicines and active substances, the increase of expensive medicines, the discrimination of generic drugs. Similar findings were observed in several literature sources $[1,3,6,8]$. For instance, a systematic review assessed the impact of ERP on European health care systems (during 2000 - 2017) [11], showing cost savings (on short-term) associated with reduced availability of medicines, delay launches and product withdrawals if manufacturers were not satisfied with the established price. A recent study has analysed the implications of implementing a proposal made by United States (US) policymakers in 2018 to introduce international reference pricing (IRP), followed by an executive order in 2020 to accelerate the process. Launching practices, currency fluctuations, affected net prices, increased prices in lower Gross Domestic Product (GDP) countries were considered as downsides of the regulation, which might change the global pharmaceutical market [19].

Policy measures focusing on both volume (demand) and price (supply) to contain health spending were mentioned in different studies [18, 23]. Some studies, for example, focused on comparisons of retail pharmaceutical cost between countries [18], others depicted spending in hospital sector [25], collected data for total pharmaceutical expenditures [13], for generic versus brand medicines, or for a certain disease or therapeutic class [2, 14, 15, 29]. Different tools and criteria were used for the analyses. In this study, we have shifted the focus from one-off discussions about brands, INNs (International Nonproprietary
Name), manufacturers or drug categories to a simple and relevant understanding of the most common and important Rx drugs (subject to regulation). Regardless of all individual characteristics and discussions, that is the core of the therapeutic act that represents the main activity and purpose of the health system.

\section{Materials and Methods}

Materials used were the market studies developed over time and provided by the Cegedim group [4]. The subject of drug spending is delicate and exposed to any more specific approach, either to scientific discussions with a therapeutic touch or to commercial discussions with the suspicion of partisan interests. Therefore, we analysed the therapeutic groups at ATC3 (Anatomical Therapeutic Chemical) level [34, 35], using a simple grouping into four categories (first 10, next 20 , next 70 , the remaining 166). They were sorted by frequency and importance and by the annual number of treatment days in 2015, the year that marked the important regulatory change.

As methods of interpretation we used the following. Analysis of the increase/decrease of absolute quantities: volume (units/boxes), value (RON), number of treatment days, consumer purchase price (RON). Analysis of the increase/decrease of the relative quantities: weight of the total. Analysis of the increase/decrease of groups of therapeutic groups.

\section{Results and Discussion}

Top 10 ATC3 groups (Rx only)

As shown in Table I, the total of Top 10 ATC 3 groups increased as volume $(+32.6 \%)$ and days of treatment $(+53.7 \%)$, but decreased in value $(-12.0 \%)$.

Table I

Top 10 ATC3 groups evolution

\begin{tabular}{|c|c|c|c|c|c|c|c|c|c|}
\hline \multirow[t]{2}{*}{ ATC3 Group } & \multicolumn{3}{|c|}{ VOLUME (mill. packs) } & \multicolumn{3}{|c|}{ VALUE CPP (mill €) } & \multicolumn{3}{|c|}{ DoT (mill.) } \\
\hline & 2010 & 2015 & 2020 & 2010 & 2015 & 2020 & 2010 & 2015 & 2020 \\
\hline C9A (ACE inhibitors, plain) & 20.8 & 19.4 & 15.8 & 75.4 & 62.2 & 46.3 & 672.0 & 719.8 & 654.8 \\
\hline $\begin{array}{l}\text { C10A (Cholesterol and triglyceride } \\
\text { regulating prep) }\end{array}$ & 8.9 & 13.0 & 18.9 & 97.9 & 87.3 & 82.0 & 206.2 & 357.3 & 537.4 \\
\hline A2B (Antiulcerants) & 11.2 & 16.4 & 20.1 & 56.7 & 57.4 & 66.4 & 198.6 & 306.8 & 418.0 \\
\hline C7A (Beta-blocking agents, plain) & 16.3 & 23.2 & 26.4 & 54.3 & 51.3 & 64.9 & 207.2 & 305.5 & 432.9 \\
\hline C8A (Calcium antagonists, plain) & 6.6 & 7.0 & 7.1 & 29.3 & 26.7 & 27.8 & 208.0 & 263.2 & 313.8 \\
\hline $\begin{array}{l}\text { C9C (Angiotensin-II antagonists, } \\
\text { plain) }\end{array}$ & 2.5 & 5.4 & 8.0 & 46.2 & 40.2 & 43.7 & 103.9 & 252.8 & 383.3 \\
\hline M1A (Anti-rheum, non-steroidal) & 20.1 & 22.7 & 22.4 & 67.3 & 63.0 & 62.7 & 224.9 & 252.6 & 278.2 \\
\hline B3X (Other anti-anaemic products) & 0.4 & 0.6 & 0.7 & 0.8 & 1.1 & 1.9 & 162.4 & 238.9 & 276.2 \\
\hline C3A (Diuretics) & 12.8 & 15.6 & 16.3 & 53.0 & 47.7 & 47.2 & 195.4 & 238.5 & 260.3 \\
\hline $\begin{array}{l}\text { C1D (Coronary therapy, excl. } \\
\text { calcium antagonists and nitrites) }\end{array}$ & 5.5 & 4.2 & 3.9 & 52.6 & 36.7 & 26.7 & 250.6 & 190.7 & 178.6 \\
\hline Top 10 Rx ATC3 & 105.2 & 127.5 & 139.5 & 533.6 & 473.7 & 469.8 & $2,429.2$ & $3,126.1$ & $3,733.5$ \\
\hline
\end{tabular}

CPP - Value of Rx Products in terms of Price Categories

However, the groups had different individual evolution in terms of volume and days of treatment: (i) significant increase: hypo-cholesterolemiants, antiulcerants, beta- blockers, angiotensin-II antagonists, anti-anaemic; (ii) growth below average: $\mathrm{Ca}$ antagonists, anti- 
rheumatics, diuretics; (iii) decreased: ACE inhibitors, coronary therapy.

However, the value generally decreased (except for antiulcerants, beta-blockers and anti-anaemia). An analysis of the Romanian cardiovascular market has showed a growth between 1998 and 2017 in volume (119.6\% in 2007 versus 1998 and 42.8\% in 2017 versus 2007) and DoT (299\% in 2007 versus 1998 and 83.9\% in 2017 compared with 2007). The top classes were the same as the cardiovascular drug groups from Table I [17]. Moreover, a study from the Netherlands during 1999 - 2014 has showed similar findings, as cardiovascular diseases are one of the most commonly noncommunicable diseases worldwide [32]. So, the widely dispensed drug classes in the Netherlands having an upward trend were: antithrombotic agents, betablocking agents, diuretic drugs and calcium channel

blockers, the highest values being observed for agents acting on the renin-angiotensin system (3.16\%), hypocholesterolemiants $(3.22 \%)$ and drugs for acid related disorders $(3.46 \%)$ [16]. In the United States, the use of prescription drugs increased from 51\% (1999 $2000)$ to $59 \%$ (2011 - 2012). A positive evolution was observed for anti-hypertensives (20 - 27\%), lipid modifying agents, represented by statins (6.9 - 17\%), drugs for acid related disorders, like proton-pump inhibitors (3.9 - 7.8\%), similar with Romanian Rx trend, followed by the use of antidepressants $(6.8-13 \%)$, antidiabetic drugs (4.6 - 8.2\%) [12]. Another study conducted in 12 European countries showed an increase in the volume of statin utilization (defined daily dose) from 2000 to 2012. The results are in line with our findings, as statins represented more than $90 \%$ of hypocholesterolemiants used in the studied countries [30].

Table II

Average Retail Price for Top 10 ATC3 groups (€)

\begin{tabular}{|l|c|c|c|c|c|c|}
\hline \multicolumn{1}{|c|}{ ATC3 Group } & \multicolumn{3}{c|}{ Average Price - Pack } & \multicolumn{3}{c|}{ Average Price - DoT } \\
\cline { 2 - 7 } & $\mathbf{2 0 1 0}$ & $\mathbf{2 0 1 5}$ & $\mathbf{2 0 2 0}$ & $\mathbf{2 0 1 0}$ & $\mathbf{2 0 1 5}$ & $\mathbf{2 0 2 0}$ \\
\hline C9A (ACE inhibitors, plain) & 3.62 & 3.21 & 2.94 & 0.11 & 0.09 & 0.07 \\
\hline C10A (Cholesterol and triglyceride reg prep) & 11.06 & 6.74 & 4.34 & 0.47 & 0.24 & 0.15 \\
\hline A2B (Antiulcerants) & 5.05 & 3.50 & 3.31 & 0.29 & 0.19 & 0.16 \\
\hline C7A (Beta-blocking agents, plain) & 3.34 & 2.21 & 2.46 & 0.26 & 0.17 & 0.15 \\
\hline C8A (Calcium antagonists, plain) & 4.46 & 3.80 & 3.93 & 0.14 & 0.10 & 0.09 \\
\hline C9C (Angiotensin-II antagonists, plain) & 18.19 & 7.44 & 5.47 & 0.44 & 0.16 & 0.11 \\
\hline M1A (Anti-rheumatics, non-steroidal) & 3.35 & 2.78 & 2.81 & 0.30 & 0.25 & 0.23 \\
\hline B3X (Other anti-anaemic products) & 1.83 & 1.65 & 2.64 & 0.00 & 0.00 & 0.01 \\
\hline C3A (Diuretics) & 4.13 & 3.07 & 2.90 & 0.27 & 0.20 & 0.18 \\
\hline C1D (Coronary therapy excl calcium antagonists and nitrites) & 9.58 & 8.66 & 6.92 & 0.21 & 0.19 & 0.15 \\
\hline Top 10 Rx ATC3 & $\mathbf{5 . 0 7}$ & $\mathbf{3 . 7 1}$ & $\mathbf{3 . 3 7}$ & $\mathbf{0 . 2 2}$ & $\mathbf{0 . 1 5}$ & $\mathbf{0 . 1 3}$ \\
\hline
\end{tabular}

The average price per pack and per day of treatment evolved also, according to Table II.

Although the average price usually decreased, similar as for the total of the first 10 groups, the individual evolution of the average price per groups was different: (i) significant decrease: hypo-cholesterolemic, angiotensin-II antagonists; (ii) decrease: ACE inhibitors, antiulcer, beta-blockers, $\mathrm{Ca}$ antagonists, anti-rheumatic, diuretics, coronary therapy; (iii) growth: anti-anaemic. The results are not that surprising, because price is only one of the factors influencing the prescription and consumption of a Rx drug, often less important than the patient's response, the possibilities of substitution over time, drug availability, validation of new therapies, new clinical data.

Decreased pharmaceutical prices were also observed in Denmark after the introduction in 2015 of the internal reference price, instead of ERP. A decrease of $22 \%$ was founded for list prices, reference prices and co-payments, generics had a high rate of reduction around $36 \%$, while branded drugs just a smaller price decrease of $2 \%$ [10]. Average drug price evolution in Romania was observed in another study conducted in 2014 to evaluate the effects of ERP policy in 26 European countries (2000 - 2012 period). Results showed a price decrease around $12 \%$, the median decrease being $15 \%$, for the pharmaceutical products taken into the study [28].

Comparing the average price per pack between the first $10 \mathrm{Rx}$ groups and all OTC products (Table III), we can raise a question mark on the fairness of this regulation which led to the decrease of the average price for these Rx groups below that of OTC.

Table III

Average Retail Price for Top 10 ATC3 groups and OTC (€)

\begin{tabular}{|l|c|c|c|}
\hline \multicolumn{1}{|c|}{ Average Price - Pack } & $\mathbf{2 0 1 0}$ & $\mathbf{2 0 1 5}$ & $\mathbf{2 0 2 0}$ \\
\hline Top 10 Rx ATC3 & $\mathbf{5 . 0 7}$ & $\mathbf{3 . 7 1}$ & $\mathbf{3 . 3 7}$ \\
\hline All OTC & 3.43 & 3.79 & 4.67 \\
\hline Top 10 Rx as \% average OTC & $\mathbf{1 4 7 . 9 \%}$ & $\mathbf{9 8 . 0 \%}$ & $\mathbf{7 2 . 1 \%}$ \\
\hline
\end{tabular}


As cardiovascular diseases are the leading cause of mortality in Romania [26], 7 of the first 10 therapeutic groups belong to cardiovascular therapy. For this reason, the discussion can be carried out in terms of shortcomings such as untreated, complicated or fatal cases, beyond the benefit of a co-payment somewhat lower, given that a higher average OTC (over-the-counter) price is paid in full by patients.

Rx evolution on groupings of ATC3 groups
Because each therapeutic group or INN is too laborious to detail, we preferred the grouping of therapeutic groups (whose evolution is found in Table IV) as a hierarchy (frequency and importance, based on the total days of treatment) as follows: (i) top 10 ATC3 groups (as detailed in Table I); (ii) top 11-30 ATC3 groups; (iii) top 31-100 ATC3 groups; (iv) the remaining (101-267) of ATC3 groups.

Table IV

Main ATC3 groupings evolution

\begin{tabular}{|l|c|c|c|c|c|c|c|c|c|}
\hline \multirow{2}{*}{ ATC3 Grouping } & \multicolumn{2}{|c|}{ VOLUME (mill. packs) } & \multicolumn{3}{c|}{ VALUE CPP (mill.€) } & \multicolumn{3}{c|}{ DoT (mill.) } \\
\cline { 2 - 11 } & $\mathbf{2 0 1 0}$ & $\mathbf{2 0 1 5}$ & $\mathbf{2 0 2 0}$ & $\mathbf{2 0 1 0}$ & $\mathbf{2 0 1 5}$ & $\mathbf{2 0 2 0}$ & $\mathbf{2 0 1 0}$ & $\mathbf{2 0 1 5}$ & $\mathbf{2 0 2 0}$ \\
\hline Top 10 ATC3 & 105.2 & 127.5 & 139.5 & 489.8 & 473.7 & 469.8 & $2,429.2$ & $3,126.1$ & $3,733.5$ \\
\hline Top 11-30 ATC3 & 102.7 & 106.5 & 115.6 & 490.6 & 535.1 & 633.0 & $1,429.5$ & $1,795.9$ & $2,275.1$ \\
\hline Top 31-100 ATC3 & 87.8 & 96.2 & 99.1 & 779.2 & 831.0 & 943.8 & 801.9 & 968.0 & $1,143.9$ \\
\hline 101-267 ATC3 & 27.4 & 29.3 & 30.7 & 428.8 & 372.2 & 780.3 & 59.8 & 67.5 & 148.3 \\
\hline Total Rx & $\mathbf{3 2 3 . 1}$ & $\mathbf{3 5 9 . 4}$ & $\mathbf{3 8 4 . 9}$ & $\mathbf{2 , 1 8 8 . 4}$ & $\mathbf{2 , 2 1 2 . 0}$ & $\mathbf{2 , 8 2 6 . 8}$ & $\mathbf{4 , 7 2 0 . 3}$ & $\mathbf{5 , 9 5 7 . 5}$ & $\mathbf{7 , 3 0 0 . 8}$ \\
\hline
\end{tabular}

The cumulative shares of these groupings are shown in Table V. We notice that the first 30 therapeutic groups accounts in 2020 for $82.3 \%$ of the total treatment days, $66.3 \%$ of the volume and $39.0 \%$ of the value and the first 100 therapeutic groups means $98.0 \%$

of the total days of treatment, $92.0 \%$ by volume and $72.4 \%$ by value. Before 2010 , a study revealed that the share of Rx drugs in Romania had increased from $2003(85.6 \%)$ to $2008(91.2 \%)$ [27], a similar trend with the grouping drugs evolution presented in Table V.

Table V

Cumulative share of ATC3 groupings

\begin{tabular}{|l|c|c|c|c|c|c|c|c|c|}
\hline \multirow{2}{*}{ ATC3 Group } & \multicolumn{3}{|c|}{ VOLUME (mill. packs) } & \multicolumn{3}{c|}{ VALUE CPP (mill $€$ ) } & \multicolumn{3}{c|}{ DoT (mill.) } \\
\cline { 2 - 10 } & $\mathbf{2 0 1 0}$ & $\mathbf{2 0 1 5}$ & $\mathbf{2 0 2 0}$ & $\mathbf{2 0 1 0}$ & $\mathbf{2 0 1 5}$ & $\mathbf{2 0 2 0}$ & $\mathbf{2 0 1 0}$ & $\mathbf{2 0 1 5}$ & $\mathbf{2 0 2 0}$ \\
\hline Top 10 ATC3 & $32.6 \%$ & $35.5 \%$ & $36.2 \%$ & $22.4 \%$ & $21.4 \%$ & $16.6 \%$ & $51.5 \%$ & $52.5 \%$ & $51.1 \%$ \\
\hline Top 30 ATC3 & $64.3 \%$ & $65.1 \%$ & $66.3 \%$ & $44.8 \%$ & $45.6 \%$ & $39.0 \%$ & $81.7 \%$ & $82.6 \%$ & $82.3 \%$ \\
\hline Top 100 ATC3 & $91.5 \%$ & $91.8 \%$ & $92.0 \%$ & $80.4 \%$ & $83.2 \%$ & $72.4 \%$ & $98.7 \%$ & $98.9 \%$ & $98.0 \%$ \\
\hline All 267 ATC3 & $100.0 \%$ & $100.0 \%$ & $100.0 \%$ & $100.0 \%$ & $100.0 \%$ & $100.0 \%$ & $100.0 \%$ & $100.0 \%$ & $100.0 \%$ \\
\hline
\end{tabular}

Table VI

Average Retail Price $(€)$ for ATC3 groupings

\begin{tabular}{|l|c|c|c|c|c|c|}
\hline \multirow{2}{*}{ Grupare ATC3 } & \multicolumn{3}{|c|}{ Average Price - Pack } & \multicolumn{3}{c|}{ Average Price - DoT } \\
\cline { 2 - 7 } & $\mathbf{2 0 1 0}$ & $\mathbf{2 0 1 5}$ & $\mathbf{2 0 2 0}$ & $\mathbf{2 0 1 0}$ & $\mathbf{2 0 1 5}$ & $\mathbf{2 0 2 0}$ \\
\hline Top 10 ATC3 & 4.66 & 3.71 & 3.37 & 0.20 & 0.15 & 0.13 \\
\hline Top 11-30 ATC3 & 4.78 & 5.03 & 5.47 & 0.34 & 0.30 & 0.28 \\
\hline Top 31-100 ATC3 & 8.87 & 8.64 & 9.53 & 0.97 & 0.86 & 0.83 \\
\hline $\mathbf{1 0 1 - 2 6 7}$ ATC3 & 15.68 & 12.70 & 25.39 & 7.18 & 5.51 & 5.26 \\
\hline Total & $\mathbf{6 . 7 7}$ & $\mathbf{6 . 1 5}$ & $\mathbf{7 . 3 4}$ & $\mathbf{0 . 4 6}$ & $\mathbf{0 . 3 7}$ & $\mathbf{0 . 3 9}$ \\
\hline
\end{tabular}

The average prices for these categories can be found in Table VI. As the average price (both per pack and per day of treatment) decreased slightly in the Top 10 ATC3, but increased in all other groups, this indicates that the saving pursued in 2015 (even if it was communicated differently) was realized at the expense of the main 10 therapeutic groups, which represent more than half of the treatment days in Romania in 2020; that is questionable regarding the normal objectives of a mature health system.

The evolution of the volume, days of treatment and retail value of ATC3 groupings are shown in Figures 1,2 and 3.
In terms of volume and days of treatment, the evolution is normal, including the visualization of the impact of the pandemic in 2020 (decrease in volume, stagnation in days of treatment). In terms of value, the anomaly of the last two segments is observed, both in terms of weight (groups 31-267), which represent a third of the volume and less than a fifth of the treatment days, means over $60 \%$ in value. That raises a question mark on the correctness of the investments of the health system in 2015 and another question mark on the sustainability of the health system. 


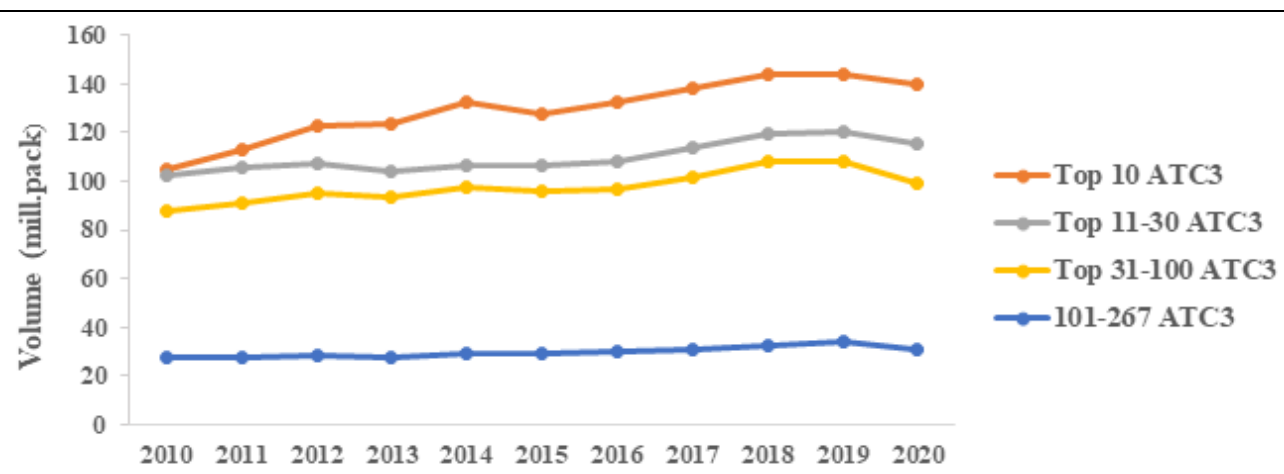

Figure 1.

Volume evolution (mill. packs) by ATC3 groupings

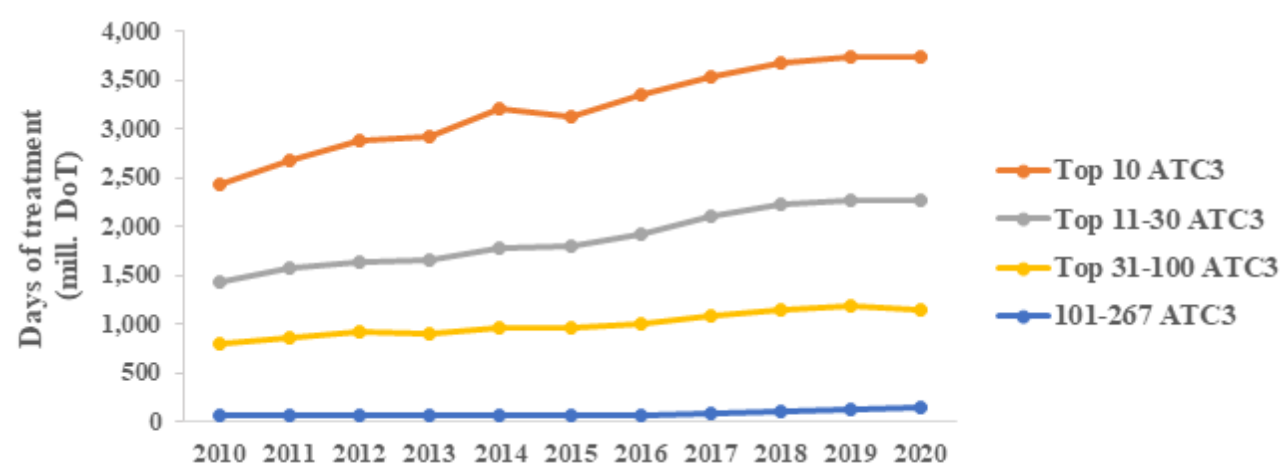

Figure 2.

Days of treatment (mill. DoT) evolution by ATC3 groupings

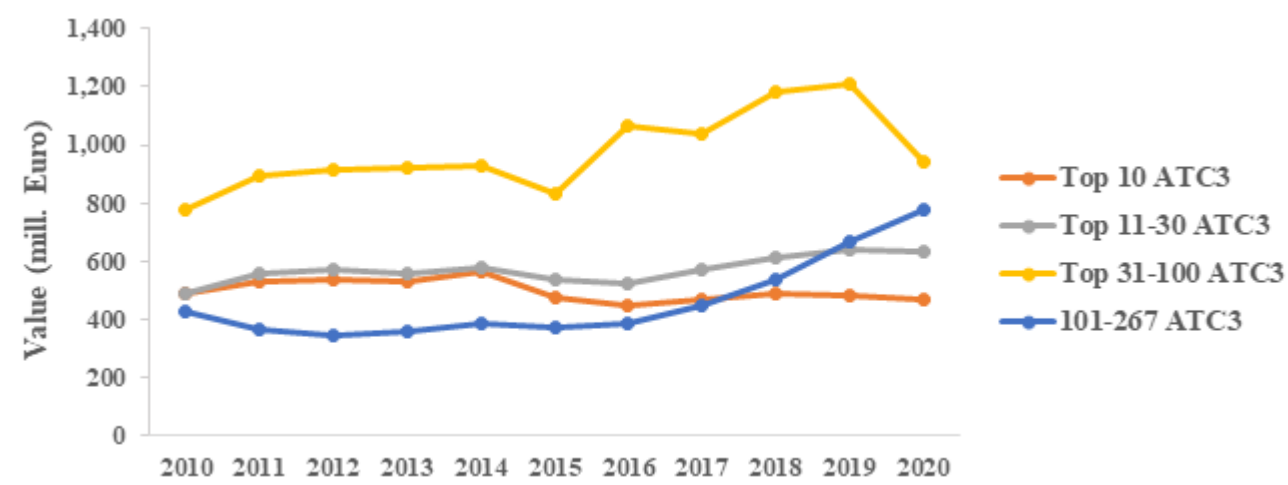

Figure 3.

Value evolution (mill. €) by ATC3 groupings

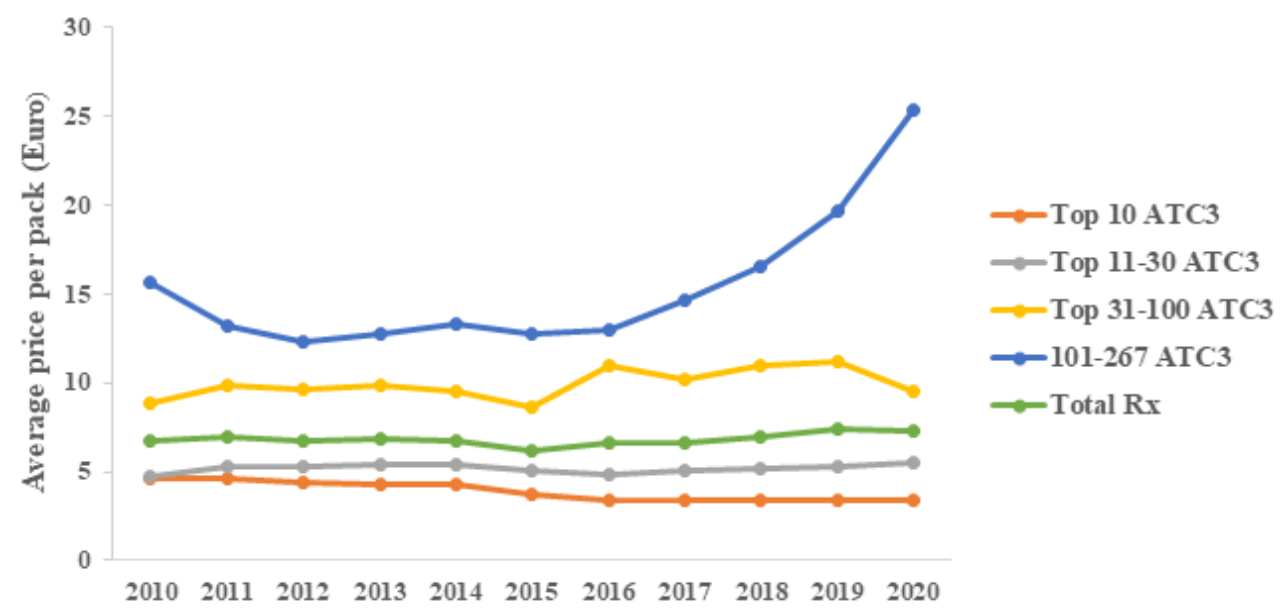

Figure 4.

Average Price per pack $(€)$ evolution by ATC3 groupings 
The evolution of the average price per pack of ATC3 groupings are shown in Figure 4, and per day of treatment in Figures 5 and 6.

Figure 4 shows that the average price per box is generally stable over time (developments are quite slow), except for the last segment (the remaining of the ATC3 groups between 101 and 267), where given the multitude of situations there is no simple explanation. It is also observed that the average price per pack for the first 100 therapeutic groups does not generally exceed significantly the threshold of $10 €$ (equivalent of 50 RON). However, in the US, the average annual retail price (calculated for the top 768 prescription drugs most used by older patients), had known an ascending trend between 2006 (4.1\%) and 2013 (12.5\%). In 2015, the average annual increase was lower comparing to the rates between 2011 (7\%) and 2014 (11.1\%), but the average Rx price of therapy per drug increased $182.9 \%$ from the end of 2005 to 2015 (calculated for $42 \%$ most used Rx drugs available 10 years on the market) [22]. These findings were expected since US had increased rate and higher prices even than highspending European countries over the time [13].

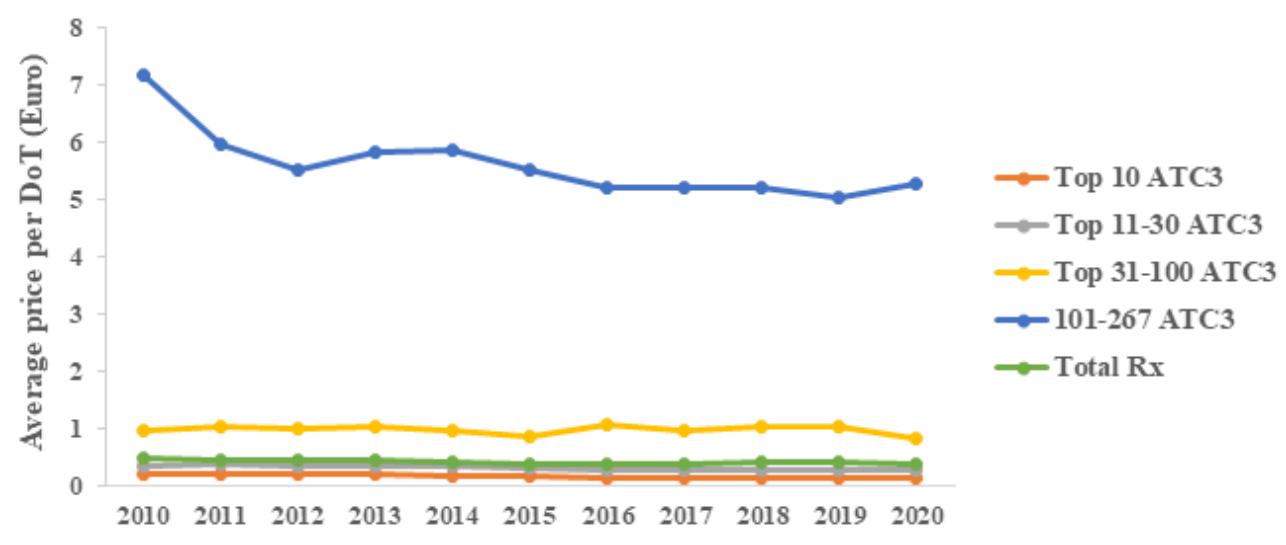

Figure 5.

Average Price per DoT $(€)$ evolution by ATC3 groupings

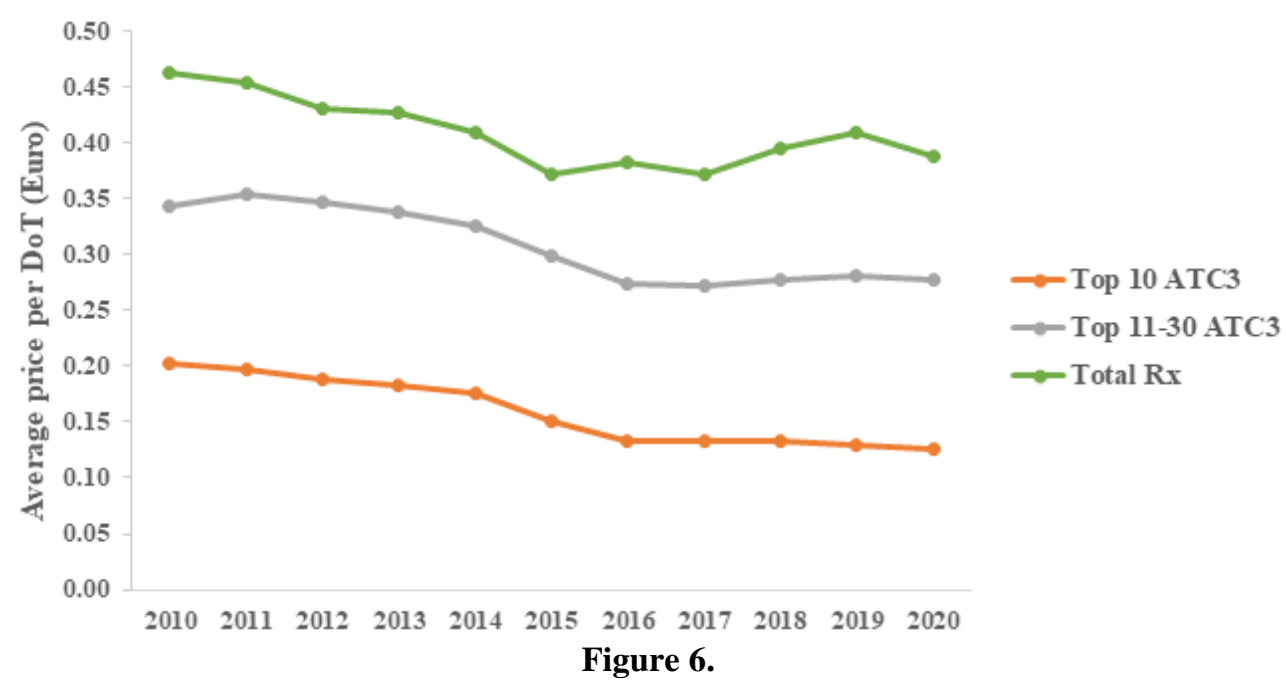

Average Price per DoT $(€)$ evolution for Top 30 ATC3 and Total Rx

The stability of average prices for Top 100 ATC3 groupings is even more obvious when we analyse the average price per day of treatment (Figure 5).

Eliminating the last two groupings, we can see in Figure 6 the evolution of the first two groupings compared to the total prescription drugs: if the average total price per day of treatment is relatively stable (slow decline) around $0.40 € /$ day, Top $11-30$ is close to $0.30 € /$ day, and the Top 10 has decreased and is relatively stable just over $0.15 € /$ day.
The rhetorical question that can be asked is how many effective frequent treatments can be provided up to $3 € /$ month (equivalent of $15 \mathrm{RON} /$ month for a patient). Unfortunately, there are quite a few.

\section{Conclusions}

Price is not the only factor that influences the prescription of $\mathrm{Rx}$ drugs and their consumption. However, 5 years after this price containment, there is a significant difference in evolution. The first 30 
therapeutic groups are "over-impacted" by this regulation, with the risk of deteriorating the availability of classic, but frequent and important treatments. The rest of the therapeutic groups "benefit" from this regulation, absorbing over $60 \%$ of the value for less than $20 \%$ of treatment days.

Although we cannot absolutize this finding, we cannot deny the anomaly found either. A coherent set of regulations is needed, in line with the main objectives of the Romanian health system. We recommend for a future regulation an average price mechanism for $\mathrm{Rx}$ drugs in therapeutic groups with an average price of up to 50 RON (equivalent of $10 €$ ) in order not to jeopardize availability and to grant accessibility properly.

The introduction of a QALY (Quality-Adjusted Life Year) principle for medicines in therapeutic groups that do not fall into the above condition, together with other specific criteria, might be a feasible and sustainable approach in terms of the current state of development of the medicine and much more appropriate for improving perspectives of drug treatment in Romania.

\section{Conflict of interest}

The authors declare no conflict of interest.

\section{References}

1. Bogaert P, Bochenek T, Prokop A, Pilc A, A qualitative approach to a better understanding of the problems underlying drug shortages, as viewed from Belgian, French and the European Union's perspective. PLos One, 2015; 10(5): e0125691: 1-20.

2. Boboia A, Florea LS, Turcu-Stiolica A, Tăerel AE, Rais C, Revnic C, Florea A, Vedeanu NS, Nastasă C, Oniga O, Decision analysis of antibiotic use. Farmacia, 2020; 68(4): 757-765.

3. Bucek Psenkova M, Visnansky M, Mackovicova S, Tomek D, Drug Policy in Slovakia. Value Health Reg Issues, 2017; 13: 44-49.

4. Cegedim, Pharma \& Hospital Report, 2010 - 2020.

5. Crăciun $P$, Pană M, Tăerel AE, Ghica M, Lupuliasa D, Consequences of the price decrease for prescription (Rx) drugs 2015 - 2019. Farmacia, 2021; 69(3): 609620.

6. Fontrier AM, Gill J, Kanavos P, International impact of external reference pricing: should national policymakers care?. Eur J Health Econ., 2019; 20(8): 11471164.

7. Gill J, Fontrier AM, Kyriopoulos D, Kanavos P, Variations in external reference pricing implementation: does it matter for public policy?. Eur J Health Econ., 2019; 20(9): 1375-1397.

8. Holtorf AP, Gialama F, Wijaya KE, Kaló Z, External Reference Pricing for Pharmaceuticals - A Survey and Literature Review to Describe Best Practices for Countries With Expanding Healthcare Coverage. Value Health Reg Issues, 2019; 19: 122-131.

9. Iravani F, Mamani H, Nategh E, External Reference Pricing and Parallel Imports of Pharmaceuticals: A
Policy Comparison. Prod Oper Manag., 2020; 29(12): 2716-2735.

10. Kaiser U, Mendez SJ, Rønde T, Ullrich H, Regulation of pharmaceutical prices: Evidence from a reference price reform in Denmark. J Health Econ., 2014; 36 : 174-187.

11. Kanavos P, Fontrier AM, Gill J, Efthymiadou O, Does external reference pricing deliver what it promises? Evidence on its impact at national level. Eur J Health Econ., 2020; 21: 129-151.

12. Kantor ED, Rehm CD, Haas JS, Chan AT, Giovannucci EL, Trends in Prescription Drug Use Among Adults in the United States From 1999-2012. JAMA., 2015; 314(17): 1818-1830.

13. Lorenzoni L, Belloni A, Sassi F, Health-care expenditure and health policy in the USA versus other highspending OECD countries. Lancet, 2014, 384(9937): 83-92.

14. Moisa C, Vlad AM, Teusdea A, Cadar O, Hoaghia MA, Lucaciu Stan R, Tăerel AE, Jurca C, Vicas L, Randomized evaluation on the consumption of antibiotics in community pharmacies. Farmacia, 2018; 66(6): 1081-1090.

15. Morgovan C, Cosma SA, Valeanu M, Juncan AM, Rus LL, Gligor FG, Butuca A, Tit DM, Bungau S, Ghibu S, An Exploratory Research of 18 Years on the Economic Burden of Diabetes for the Romanian National Health Insurance System. Int J Environ Res Public Health, 2020; 17(12): 4456: 1-16.

16. Oktora MP, Denig P, Bos JHJ, Schuiling-Veninga $\mathrm{CCM}$, Hak E, Trends in polypharmacy and dispensed drugs among adults in the Netherlands as compared to the United States. PLoS ONE, 2019; 14(3): e0214240: 1-15.

17. Pană M, Crăciun $\mathrm{P}$, Nicolae $\mathrm{C}$, Tăerel $\mathrm{AE}$, Lupuliasa D, The cardiovascular market in Romania during 1998 2017 period - analysis and evolution. Farmacia, 2019; 67(5): 922-930.

18. Panteli D, Arickx F, Cleemput I, Dedet G, Eckhardt H, Fogarty E, Gerkens S, Henschke C, Hislop J, Jommi C, Kaitelidou D, Kawalec P, Keskimaki I, Kroneman M, Bastida JL, Barros PP, Ramsberg J, Schneider P, Spillane S, Vogler S, Vuorenkoski L, Kildemoes HW, Wouters O, Busse R, Pharmaceutical regulation in 15 European countries. Review. Health Syst Transit., 2016; 18(5): 1-122.

19. Rand LZ, Kesselheim AS, International Reference Pricing for Prescription Drugs in the United States: Administrative Limitations and Collateral Effects. Value Health, 2021; 24(4): 473-476.

20. Rajkumar $\mathrm{V}$, The high cost of prescription drugs: causes and solutions. Blood Cancer J., 2020; 10(6): 71: 1-5.

21. Rémuzat C, Urbinati D, Mzoughi O, Hammi EE, Belgaied W, Toumi M, Overview of external reference pricing systems in Europe. J Mark Access Health Policy, 2015; 3: 1-11.

22. Schondelmeyer SW, Purvis L, Trends in retail prices of prescription drugs widely used by older Americans: 2006-2015. AARP Public Policy Institute, 2017; 121.

23. von der Schulenburg F, Vandoros S, Kanavos P, The effects of drug market regulation on pharmaceutical prices in Europe: overview and evidence from the 
market of ACE inhibitors. Health Econ Rev., 2011; 1(1): $18: 1-8$

24. Schumock GT, Li EC, Suda KJ, Matusiak LM, Hunkler RJ, Vermeulen LC, Hoffman JM, National trends in prescription drug expenditures and projections for 2014. Am J Health Syst Pharm., 2014; 71(6): 482-499.

25. Schumock GT, Li EC, Wiest MD, Suda KJ, Stubbings J, Matusiak LM, Hunkler RJ, National trends in prescription drug expenditures and projections for 2017. Am J Health Syst Pharm., 2017; 74(15): 1158-1173.

26. Simionescu M, Bilan S, Gavurova B, Bordea EN, Health Policies in Romania to Reduce the Mortality Caused by Cardiovascular Diseases. Int J Environ Res Public Health, 2019; 16(17): 3080: 1-9.

27. Tăerel AE, Turcu-Stiolică A, Study on the range of drugs authorized in Romania - A determinant element for the accessibility and availability of drugs. Farmacia, 2009; 57(2): 254-259.

28. Tuomi M, Remuzat C, Vataire AL, Urbinati D, External Reference Pricing of Medicinal Products: SimulationBased Considerations for Cross-Country Coordination. European Commission Report, 2013: 1-13.
29. Tataringa G, Stan C, Mircea C, Zbancioc AM, Novel therapeutic options for old drugs. Rev Med Chir Soc Med Nat Iasi, 2019; 123(2): 364-372.

30. Vancheri F, Backlund L, Strender L, Godman B, Wettermark B, Time trends in statin utilisation and coronary mortality in Western European countries. BMJ Open, 2016; 6(3): e010500: 1-7.

31. Vogler S, Paris V, Ferrario A, Wirtz VJ, Kees J, Schneider P, Pedersen HB, Dedet G, Babar Z, How Can Pricing and Reimbursement Policies Improve Affordable Access to Medicines? Lessons Learned from European Countries. Appl Health Econ Health Policy, 2017; 15(3): 307-321.

32. World Health Organization (WHO), Noncommunicable diseases country profiles 2018. Geneva: World Health Organization, 2018: 1-223.

33. Foundation Note-Government Decision number 800/ 26.10.2016, http://gov.ro.

34. Anatomical Therapeutic Chemical Classification, www.who.int.

35. The Anatomical Classification of Pharmaceutical Products by the European Pharmaceutical Market Research Association (EphMRA), www.ephmra.org. 